\title{
Tobacco industry success in preventing regulation of secondhand smoke in Latin America: the "Latin Project"
}

\section{J Barnoya, S Glantz}

Tobacco Control 2002;11:305-314

See end of article for authors' affiliations ......................

Correspondence to: Professor Stanton A Glantz, $\mathrm{PhD}$, University of California, Box 0130, San Francisco, CA 94143-0130, USA glantz@medicine.ucsf.edu

Received 20 May 2002 and revision requested 17 August 2002. Accepted 10 September 2002

\begin{abstract}
Objective: To examine the tobacco industry's strategy to avoid regulations on secondhand smoke exposure in Latin America.

Methods: Systematic search of tobacco industry documents available through the internet. All available materials, including confidential reports regarding research, lobbying, and internal memoranda exchanged between the tobacco industry representatives, tobacco industry lawyers, and key players in Latin America.

Results: In Latin America, Philip Morris International and British American Tobacco, working through the law firm Covington \& Burling, developed a network of well placed physicians and scientists through their "Latin Project" to generate scientific arguments minimising secondhand smoke as a health hazard, produce low estimates of exposure, and to lobby against smoke-free workplaces and public places. The tobacco industry's role was not disclosed.

Conclusions: The strategies used by the industry have been successful in hindering development of public health programmes on secondhand smoke. Latin American health professionals need to be aware of this industry involvement and must take steps to counter it to halt the tobacco epidemic in Latin America.
\end{abstract}

$\mathrm{T}$ he effects of secondhand smoke (SHS) pose a serious problem for the tobacco industry because increasing public awareness of SHS's dangers leads to smoke-free indoor air laws, ${ }^{12}$ which reduce the social acceptability of smoking and lower cigarette consumption, ${ }^{3}$ thus decreasing industry revenues and profits. ${ }^{4}$ The tobacco industry has used several strategies to counter the evidence that SHS is dangerous and avoid legislation and regulations, including hiring scientists sympathetic to its position on SHS, ${ }^{5}$ using public relations firms and lawyers to create controversy about health effects of SHS, ${ }^{67}$ and infiltrating international health organisations such as the International Agency for Research on Cancer. ${ }^{8}$ As it has with active smoking since the 1950s, ${ }^{9}$ since the 1970s the tobacco industry has used its lawyers to secretly hire scientists to contest the evidence that SHS causes disease in the USA. ${ }^{6} 10^{11}$ In the late 1980s the industry expanded this effort by forming an "international ETS [environmental tobacco smoke, what the industry calls SHS] consultants program" to respond to the SHS threat worldwide. ${ }^{5}$

Latin America is an important region for the tobacco industry. ${ }^{12}$ To prevent the spread of smoke-free workplace and public place legislation and regulations from North America, Philip Morris International (PMI) and British American Tobacco (BAT) initiated the "Latin Project" in 1991 "in anticipation of, rather than in reaction to, the full-force arrival of the ETS issue to Central and South America" ${ }^{13}$ Through the Latin Project, the industry recruited well placed medical and scientific consultants and funded them to publish research on indoor air quality (IAQ), publish reviews challenging the science linking SHS and disease, organise regional symposia (for both scientists and the media), and lobby to support its political needs. These efforts were successful; smoke-free environment measures in Latin American remain weak and rarely enforced..$^{12}$

\section{METHODS}

Between July 2001 and March 2002 we searched tobacco industry documents internet sites (University of California
San Francisco Legacy Tobacco Documents Library http:// legacy. library.ucsf.edu/ and BAT collection www.library. ucsf.edu/tobacco/batco/; Philip Morris www.pmdocs.com; Tobacco Documents Online www.tobaccodocuments.org). In addition, we obtained documents by visiting the BAT Guilford Depository in England. We initially searched on "Latin America". After identifying key players and countries, we searched using names, locations, dates, and reference (Bates) numbers.

PMI and BAT were they main sources of documents; their Latin American subsidiaries control more than $90 \%$ of the market. ${ }^{12}$

\section{RESULTS}

Table 1 presents a time line of the main events of the Latin Project.

\section{The Latin Project}

In 1992, the Latin Project was financed by BAT (60\%) and PMI $(40 \%)$ and administered by lawyer John Rupp of the Washington, DC law firm of Covington \& Burling (C\&B), ${ }^{13-16}$ which manages tobacco industry projects to oppose SHS restrictions worldwide. ${ }^{517}$ The 1994 Latin Project budget C\&B suggested was $\$ 680000,{ }^{18}$ including C\&B's $\$ 105000$ fee. C\&B attorneys would recruit, pay, and assist Latin American medical and scientific consultants to prepare materials and presentations under retainer agreements they signed with $\mathrm{C} \& \mathrm{~B} .{ }^{18}$ The rest of the budget was for work to be done by consultants. The 1993 PMI regional public affairs plan and budget for the Latin Project describes the project:

Abbreviations: BAT, British American Tobacco; CATANA, C.A Tabacalera Nacional; CIAR, Center for Indoor Air Research; CIESPAL, Céntro de Estudios Superiores en Comunicación para América Latina; ETS, environmental tobacco smoke; IAQ, indoor air quality; PAHO, Pan American Health Organization; PMl, Philip Morris International; SHS, secondhand smoke 


\begin{tabular}{|c|c|}
\hline 1991 & $\begin{array}{l}\text { - Latin Project initiated by PM and BAT "in anticipation of, rather than in reaction to, } \\
\text { the full-force arrival of the ETS issue to Central and South America." }{ }^{\prime \prime 3} \\
\text { - C\&B to handle the project to avoid industry exposure }\end{array}$ \\
\hline 1992 & $\begin{array}{l}\text { - Central American Field Study started by Maria Alfaro and Cesar Gonzalez } \\
\text { - CIAR funds study in offices and restaurants in Sao Paulo, Brazil } \\
\text { - Argentinian President Menem vetoes "The Neri Bill" }\end{array}$ \\
\hline 1993 & $\begin{array}{l}\text { - Thirteen consultants had already been recruited from Argentina, Venezuela, Chile, } \\
\text { Guatemala, Costa Rica, Ecuador, and Brazil } \\
\text { - Carlos Alvarez and Bruno Burger publish the review "Relation of smoking in the } \\
\text { environment with coronary disease"86 } \\
\text { - The CIESPAL symposium is held in Quito, Ecuador }\end{array}$ \\
\hline 1995 & $\begin{array}{l}\text { - The "Second International Symposium on New Advances in Ambient Air and } \\
\text { Cardio-respiratory Illnesses" is held in Buenos Aires, Argentina } \\
\text { - Lionel Gil publishes the paper entitled "Influence of outdoor pollution on indoor air } \\
\text { quality" }\end{array}$ \\
\hline 1998 & $\begin{array}{l}\text { - CIAR funds Antonio Miguel to conduct a study on IAQ in Brazil and Chile } \\
\text { - Last documents found that evidence that the project is still running in } 1998\end{array}$ \\
\hline
\end{tabular}

[The Latin Project] aims to generate high quality scientific data, literature and commentary that can be used to respond persuasively to what is expected to be an increasing number of exaggerated media claims of adverse health effects from ETS exposure as well as to oppose government initiatives to ban or restrict smoking in public places. . . . [and develop] solid scientific data not only with respect to ETS specifically but also with respect to the full range of potential indoor and outdoor contaminants. ${ }^{13}$ [emphasis added]

"Solid scientific data" in this context means data that support the industry's position that SHS is not a health threat or not a significant problem when compared to other sources of indoor air pollution..$^{10}$

The Latin Project did not include all Latin American countries. At a 1993 Miami meeting between PMI, BAT, and C\&B, "It was decided that the industry would take action only in those markets where the report [1992 US Environmental Protection Agency report that identified SHS as a Class A human carcinogen ${ }^{19}$ ] received wide media coverage." ${ }^{20}$ As Rupp informed BAT: "ETS activities in South and Central America should be dictated by the market themselves."21 By 1993, the Latin Project recruited 13 consultants from "Argentina, Brazil, Chile, Costa Rica, Ecuador, Guatemala and Venezuela. The consultants represent a wide variety of scientific disciplines, including chemistry and biochemistry, epidemiology, oncology and pulmonary and cardiovascular medicine." ${ }^{13}$

The Latin Project continued through at least $1998^{22-25}$ and may still be active; we found no evidence that it was terminated.

\section{Recruiting, training, and managing consultants}

PM and BAT provided C\&B with a list of suggested consultants. C\&B selected and hired the consultants to build the Latin American ETS Consultant Program. Efforts were made to reach "a balance between those [consultants] able to do research and those able to address the medical/health issues." ${ }^{26}$ The ideal consultant's profile included "Preferably a former minister, a Dean of a medical school or member of a National Academy of Science. Good public speaking skills." ${ }^{27}$

A 1991 memorandum to the PMI representatives in Argentina, Brazil, Costa Rica, Ecuador, and Venezuela from Cesar Rodriguez (in 1995, vice president, Tobacco Category, PMI LA Region $^{28}$ ) explains that $\mathrm{C} \& \mathrm{~B}$ handled the programme, "In order to ensure independence from the tobacco industry" ${ }^{\prime 2}$ and to avoid public recognition of the industry's involvement. Rodriguez notes that industry representatives should not contact candidate consultants and that contacts would be made "solely" by $\mathrm{C} \& \mathrm{~B}^{29}$ a policy reaffirmed in a 1993 Miami meeting of PMI, BAT, and C\&B. ${ }^{20}{ }^{30}$ Despite this "independence" from the industry, Rodriguez spelled out in detail the consultants' duties:

1) Write letters and editorials to newspapers

2) Write ETS/health related articles for press and scientific journals

3) Participate in scientific conferences either as a presentor [sic] or attendee

\section{4) Conduct media interviews}

5) Monitor smoking and health activities

6) Act as a troubleshooter to defuse a particular situation in which the tobacco industry should not be directly involved. ${ }^{29}$ [emphasis added]

These duties are the same the industry had for participants in its International ETS Consultant Program. ${ }^{17}$

C\&B's Rupp signed retainer agreements in which at least one consultant in each country was paid a fee to be available to assist the industry. ${ }^{18} 31$ The 1994 budget for retainer agreements was $\$ 210000$, ranging from $\$ 10000$ to $\$ 50000$ per consultant ${ }^{18}$ (table 2 ).

A 1991 memorandum describes how and why Venezuelan consultant Dr Bruno Burger was selected:

Dr. Bruno Burger is a Harvard-educated cardiologist who speaks excellent English. He teaches and conducts research at a prestigious teaching hospital in Caracas.

Dr. Burger is also handsome and articulate. In many ways he seems the perfect candidate. It may be, however, that he has already been identified as a friend of the tobacco industry. He knows many of the people at the local companies, and the automobile races at which he announces are sponsored by the [tobacco] companies. $^{32}$ 
Table 2 Known individuals who participated in the Latin Project

\begin{tabular}{|c|c|c|c|c|}
\hline Name & Country & Affiliation & Activities & Payment for 1994 \\
\hline Dr Maria del Rosario Alfaro & Costa Rica & $\begin{array}{l}\text { National University of Costa } \\
\text { Rica }^{60}\end{array}$ & $\begin{array}{l}\text { Central American Field Study, author of } \\
\text { CIESPAL summary }{ }^{38}\end{array}$ & $\$ 25000^{1462}$ \\
\hline Dr Carlos B Alvarez & Argentina & $\begin{array}{l}\text { Director of the Institute of } \\
\text { Cardiovascular Clinics }\end{array}$ & $\begin{array}{l}\text { Review relationship between SHS and CHD, } \\
\text { lobbied President Menem, and Buenos Aires } \\
\text { symposium organiser }{ }^{41} 86\end{array}$ & $\$ 50000^{14}$ \\
\hline Dr Francisco Aquino Neto & Brazil & \multicolumn{2}{|c|}{$\begin{array}{l}\text { Professor of Chemistry, Federal Initial training session and IAQ study }{ }^{70} \\
\text { University of Rio de Janeiro }\end{array}$} & $\mathrm{NA}^{32}$ \\
\hline AmbioConsult & Venezuela & NA & IAQ study in Caracas & $\$ 20000^{14}$ \\
\hline Dr Alonso Armijos Luna & Ecuador & $\begin{array}{l}\text { National University of Loja } \\
\text { Medical School (Dean) }\end{array}$ & Initial training session ${ }^{26}$ & NA \\
\hline Dr Luiz Britto & Brazil & NA & Contact developed in $1997^{23}$ & NA \\
\hline Dr Pedro Buckler & Brazil & NA & Monitor government activities & $\begin{array}{l}\text { Membership fee in the } \\
\text { Brazilian IAQ Society }{ }^{24}\end{array}$ \\
\hline Dr Bruno Burger & Venezuela & $\begin{array}{l}\text { Chief of Cardiology, Centro } \\
\text { Médico Docente, Caracas, } \\
\text { Venezuela }{ }^{32}\end{array}$ & $\begin{array}{l}\text { Review: Relationship between SHS and } \\
\mathrm{CHD}^{4186}\end{array}$ & $\$ 10000^{14}$ \\
\hline Dr Jari Cardoso Nobrega & Brazil & \multicolumn{2}{|c|}{$\begin{array}{l}\text { Professor of Chemistry, Federal Initial training session and IAQ study }{ }^{70} \\
\text { University of Rio de Janeiro }\end{array}$} & $\mathrm{NA}^{32}$ \\
\hline Dr Hector Croxatto & Chile & Catholic University of Chile & Initial training session & $\mathrm{NA}^{32}$ \\
\hline Dr Osvaldo Fustinoni & Argentina & $\begin{array}{l}\text { President of the National } \\
\text { Academy of Sciences of } \\
\text { Buenos Aires }\end{array}$ & Buenos Aires symposium ${ }^{41}$ & $\mathrm{NA}^{32}$ \\
\hline Dr Lionel Gil (toxicologist) & Chile & $\begin{array}{l}\text { University of Chile Medical } \\
\text { School }^{2662}\end{array}$ & $\begin{array}{l}\text { Influence of outdoor pollution on IAQ paper } \\
\text { published }\end{array}$ & $\$ 20000^{14}$ \\
\hline \multicolumn{2}{|c|}{ Dr Luis Fernando de Goes SiqueiraBrazil } & NA & $\mid A Q$ study in Chile and Brazil| ${ }^{71}$ & NA \\
\hline Dr Cesar L Gonzalez C & Guatemala & $\begin{array}{l}\text { University of San Carlos, } \\
\text { School of Medicine }{ }^{57}\end{array}$ & Central American Field Study ${ }^{38}$ & $\$ 10000^{14}$ \\
\hline Dr Eduardo Gros & Argentina & $\begin{array}{l}\text { Professor of Organic } \\
\text { Chemistry, University of } \\
\text { Buenos Aires }\end{array}$ & Initial training session & $\mathrm{NA}^{32}$ \\
\hline Guillermo Guesse (architect) & Chile $^{26}$ & NA & NA & NA \\
\hline Dr Ricardo Katz & Chile & NA & $\begin{array}{l}\text { Monitor government activities on IAQ } \\
\text { regulations }{ }^{24}\end{array}$ & NA \\
\hline Dr Remigio Lopez (biochemist) & Chile & $\begin{array}{l}\text { University of Chile Medical } \\
\text { School. }^{26}\end{array}$ & Influence of outdoor pollution on IAQ ${ }^{40}$ & $\$ 15000^{14}$ \\
\hline Dr Raoul Mattera & Argentina & NA & Monitor anti-tobacco legislation ${ }^{111}$ & NA \\
\hline Dr Antonio Miguel & Brazil & University of Sao Paulo ${ }^{32}$ & IAQ study in Chile and Brazil (1998) 7072 & $\$ 20000^{14}$ \\
\hline Dr Celio Paul Motta & Brazil & Epidemiologist & Initial training session & $\mathrm{NA}^{32} 112$ \\
\hline Dr Jean Raad & Ecuador & NA & $\begin{array}{l}\text { IAQ study in Ecuador and attended Tokyo } \\
\text { Symposium }{ }^{39} 62\end{array}$ & $\$ 20000^{14}$ \\
\hline Dr Francisco Radler & Brazil & NA & $\begin{array}{l}\text { Monitor government activities on IAQ } \\
\text { regulations }{ }^{24112}\end{array}$ & NA \\
\hline Dr Juan Tenorio & Ecuador & Upjohn Company in Quito & $\begin{array}{l}\text { Translations for Dr Raad in Tokyo } \\
\text { symposium }^{39}\end{array}$ & $\$ 1000^{39}$ \\
\hline Dr Sergio Tezanos-Pinto & Chile & University of Valparaiso ${ }^{26}$ & Initial training session & $\mathrm{NA}^{113}$ \\
\hline Dr Eduardo Souchon & Venezuela & NA & Initial training session & $\mathrm{NA}^{113}$ \\
\hline
\end{tabular}

Prior public connection with the tobacco industry was considered a liability. The industry preferred experts who would appear neutral commentators to decision makers and the media. Nevertheless, they retained him.

In addition to individual consultants, AmbioConsult, a Venezuelan based environmental consultant company (http:// sicavecon.true.net/afilamb.htm accessed 25 March 2002), was retained to assist the consultants in developing IAQ research. $^{21}$

$\mathrm{C} \& \mathrm{~B}$ provided the consultants with publications prepared by other tobacco industry scientific consultants that support the industry's position on SHS. ${ }^{20} 33$ The conclusions of the monograph summarising the results of a widely distributed industry sponsored symposium, Environmental tobacco smoke: proceedings of the international symposium at McGill University, ${ }^{35}$ are typical: "One of the most striking consensus views emanating from this conference is that the published data, when critically examined and evaluated, are inconsistent with the notion that ETS is a health hazard." ${ }^{35}$

This monograph was translated into Spanish ${ }^{21} 3637$ and distributed in each country to selected government officials, politicians, and health personnel..$^{20}{ }^{38-42}$ The book Other people's tobacco smoke, ${ }^{43}$ which was written by another consultant for non-technical audiences, would also be translated to Spanish $^{21}$ and printed by the University of Chile Press. ${ }^{40}$
The industry trained its consultants ${ }^{44}$ so that they would be seen by the public and media as experts on SHS by sending them to industry funded international IAQ symposia to make presentations. (Since the industry controls these symposia, ${ }^{45}$ it is not a problem getting the consultants on the programme.) C\&B justified a $\$ 40000$ expense for travel and participation in these meetings because "Presentations by the consultants at such seminars not only promotes their standing in the international scientific community but provide bases for local and regional media initiatives as well." ${ }^{18}$

For example, Rupp reported that Ecuadorian consultant Dr Jean Raad's attendance at the 1993 industry sponsored Tokyo Symposium was "part of an effort to bolster Dr. Raad's expertise on ETS, while providing a focus for [his] articles and other writings." ${ }^{39}$ Rupp, however, expressed concern about Raad's claim to SHS expertise independent of the tobacco industry:

The problem is that, apart from his general medical training, Dr. Raad cannot point to any experience giving him unique or specialized expertise on ETS. We [C\&B] certainly do not want him [Dr. Raad] to say, in response to an inquiry from a member of the press or colleague, that a major part of his expertise stem from ETS training/ orientation sessions that he has attended that have been put together by a couple of tobacco companies. What is 
Table 3 Some industry funded indoor air quality (IAQ) studies in Latin America

\begin{tabular}{|c|c|c|c|}
\hline Name (year) & Contributors & $\begin{array}{l}\text { Publication/promotion } \\
\text { (if known) }\end{array}$ & Budget \\
\hline $\begin{array}{l}\text { Central American Field Study } \\
\text { (1992-93) }\end{array}$ & Alfaro Gonzalez & CIESPAL symposium ${ }^{62}$ & $\begin{array}{l}\$ 136000 \text { (CIAR and } \\
\text { Latin Project) }^{38} 60114\end{array}$ \\
\hline IAQ Study, Argentina (1994) & $\begin{array}{l}\text { Argentine consultants with } \\
\text { Gil or Ambioconsult }\end{array}$ & NA & $\$ 150000^{1314}$ \\
\hline $\begin{array}{l}\text { IAQ Study in Quito, Ecuador } \\
\text { (1993) }\end{array}$ & Raad with $\mathrm{HBI}^{*}$ & CIESPAL symposium ${ }^{62}$ & NA \\
\hline $\begin{array}{l}\text { Characterisation of IAQ in the } \\
\text { cities of Sao Paulo and Rio, } \\
\text { Brazil (1993) }\end{array}$ & $\begin{array}{l}\text { Miguel, Aquino Neto, } \\
\text { Cardoso }\end{array}$ & $\begin{array}{l}\text { Environmental Science } \\
\text { and Technology }\end{array}$ & $\begin{array}{l}\$ 72760(\mathrm{CIAR}) \\
(1992-93)^{70}\end{array}$ \\
\hline IAQ Study, Chile (1994) & Gil & $\begin{array}{l}\text { Revista Medica } \\
\text { Chilena }^{81}\end{array}$ & $\$ 100000^{13}$ \\
\hline $\begin{array}{l}\text { Sick Building Syndrome Study, } \\
\text { Brazil (1994) }\end{array}$ & Siqueira, Cardoso, Miguel & NA & $\$ 50000^{1418}$ \\
\hline Aircraft Study, Brazil (1994) & $\begin{array}{l}\text { Consultants from Federal } \\
\text { University of Rio de Janeiro }\end{array}$ & NA & $\$ 15000^{14}$ \\
\hline IAQ Study, Venezuela (1993) & Lcd. Elba Contreras & CIESPAL symposium ${ }^{62}$ & $\$ 100000^{13}$ \\
\hline
\end{tabular}

*Tobacco industry funded Healthy Building International; NA, not available.

needed is some independent source of expertise, complementing his general medical training, that he can rely upon if challenged. ${ }^{46}$ [emphasis added]

This concern underscores the fact that the industry sought to provide a "third party" voice that supported their position.

Dr Carlos Alvarez (Argentina) was invited to the Tokyo symposium to serve on the panel on the relationship between SHS and cardiovascular disease. ${ }^{41}$ He would also be joined by a "prominent" Argentine journalist. The goal was to "stimulate a series of articles on ETS in the Argentina media, written by Dr. Alvarez as well as by the journalist accompanying him to the Tokyo meeting. Muy Interesante and Salud are two possible target publications." ${ }^{\prime 1}$ Alvarez and the journalist would also receive travel expenses plus an honorarium. In addition, Alvarez was invited to an IAQ conference held in Athens, Greece, in 1992. His attendance received wide media coverage in Argentina. ${ }^{47-53}$ Patrick Davies (C\&B) would write the format and points that Alvarez should address in the press conferences. $^{54}$

Consultants would also write articles and letters for local newspapers and magazines, as the industry had its US consultants do. ${ }^{55}$ In Latin America, each consultant was given a number of articles to write, and when available, they would use results from industry funded studies as their arguments against tobacco control.

The industry was also very careful not to overexpose them. For example, Alvarez was to:

respond promptly to media articles misrepresenting [from the industry's perspective] the science of ETS or calling for smoking restrictions for scientifically unjustified reasons. Dr. Alvarez will be told that journalists will be invited by industry representatives to contact him directly and that, in the event that no such direct contact take place, he is expected to write letters to the editors of reporting newspapers and magazines. A maximum of four letters per year would be expected from Dr. Alvarez in order to prevent his overexposure. ${ }^{14}$ [emphasis added]

Likewise, Dr Alfaro (Costa Rica) was expected to:

Prepare and place three articles in popular magazines or newspapers. One of the articles would report on the Buenos Aires symposium. Another would propose priorities for Costa Rica and other Central American countries for addressing outdoor and indoor air quality problems. The third would address indoor air quality problems in home. $^{14}$

\section{Shifting the focus from SHS to other environmental pollutants}

Research projects on IAQ were funded and published by the industry to generate "high quality scientific data"13 to support its position on SHS. Projects results were distributed to the general public and policymakers, as noted in a confidential memo from C\&B:

[Public awareness] of the indoor effects of outdoor pollution is not a "solution" to the regulatory pressures about ETS. Policymakers could easily decide that actions about both [outdoor pollution and ETS] are proper ingredients of an overall indoor air strategy.

An emphasis upon outdoor pollutants is therefore a potentially significant ingredient of an overall ETS strategy, but that strategy must also include steps specifically addressed to the regulatory threats surrounding ETS as such. ${ }^{56}$

Research projects were funded to support these goals (tables 2 and 3 ).

Starting in 1992, the Central American Field Study conducted by Alfaro and Dr Cesar Gonzalez (Guatemala) monitored IAQ in restaurants, offices, and public buildings in Guatemala, and hospitals in Panama, El Salvador, Nicaragua, Honduras, and Costa Rica. ${ }^{387-59}$ Alfaro was chief of the Research Program of Environmental Pollution in Costa Rica and director of the Pollution Laboratory at the National University of Costa Rica. Gonzalez was a member of the Faculty of Scientific Medicine, University of San Carlos de Guatemala and with the Department of Central Laboratories of the Ministry of Public Health. ${ }^{57}$ BAT and PMI provided $\$ 60000$ and $\$ 50000$, respectively, to finance the study, with the rest from the Latin Project budget. The money was funnelled through the tobacco industry's Center for Indoor Air Research (CIAR). ${ }^{3857}{ }^{60}$ (The CIAR served as a device to provide tobacco industry money to consultants through "special projects" administered by industry lawyers rather than scientists. $^{571161}$ )

Preliminary results of the Central American Field Study were presented in an industry funded public symposium held at the media education organisation Céntro de Estudios Superiores en Comunicación para América Latina (CIESPAL) in 
Quito, Ecuador. ${ }^{62}$ A draft of the study results were edited by Rupp and BAT scientist Chris Proctor, ${ }^{63}{ }^{64}$ but they were not listed as authors or acknowledged in the study. Publication of the results in an international journal was mentioned by Alfaro in a meeting held in Costa Rica between industry representatives and Costa Rican consultants. ${ }^{65}$ According to Rupp "she [Alfaro] would like to submit the study results to a journal published in the United States, in part because such journals are widely regarded in Costa Rica as being preeminent sources of scientific information." ${ }^{38}$

Alfaro eventually published an article in Indoor e Built Environment. ${ }^{66}$ The article presents results from IAQ monitoring study in Central America. PMI paid Alfaro \$1851 for the preparation of the manuscript. ${ }^{67-69}$

In Argentina, 1993 PMI's Regional public affairs plan and budget for Latin America included an IAQ study of offices and restaurants identified as potential targets for smoking restrictions. Consultants from an Argentine university would be recruited and collaborate with Chilean consultant Dr Lionel Gil or AmbioConsult. ${ }^{18}$

In Brazil, in 1992 CIAR provided $\$ 72760$ (for the first 12 months) for Miguel, Jari Cardoso, and Aquino Neto to study IAQ in offices and restaurants in Rio de Janeiro and Sao Paulo. ${ }^{70}$ As with the Central American Field Study draft paper, Miguel sent a draft to $C \& B$ lawyers for review and approval. The C\&B lawyers reported

\section{we [Davies and Rupp] received a very solid draft from Dr. Miguel last week, which [BAT scientist] Chris Proctor and we reviewed and approved with only minor sugges- tions for revision. We expect to receive the revised draft from Dr. Miguel in double-spaced form today, which will allow us to perform a light English edit on the paper before it is submitted to Environmental Science and Technology [published by the American Chemical Society]..$^{.3}$}

Miguel's paper, "Characterization of indoor air quality in the cities of Sao Paulo and Rio de Janeiro, Brazil,"71 acknowledges funding from CIAR, but does not mention Davies, Rupp, and Proctor's role in preparing it.

C\&B's 1994 Latin Project budget included \$50 000 for Brazilian consultants working with AmbioConsult in a Brazilian sick building syndrome study in Sao Paulo. The study, done by Siqueira, Jari Cardoso, and Miguel, would be used by Miguel to respond to media articles that "misrepresent the science of ETS" $^{14}$

In 1998 CIAR funded Miguel for a study titled “Acquisition of source signatures and receptor modelling of fine particles and VOC Impacting indoor air quality in Santiago de Chile and Sao Paulo, Brazil." ${ }^{72-75}$ The study monitored IAQ in two metropolitan areas of Santiago, Chile, and Sao Paulo, Brazil, based on the hypothesis that the net transport of fine particles and gaseous species from outdoor ambient (not SHS generated indoor) air accounts for a significant fraction of indoor air aerosol concentrations. Regarding SHS, "Results would give a fair assessment of IAQ, since the preferred ventilation mechanism might be to open the windows." ${ }^{73}$

In 1993, consultants published four abstracts ${ }^{76-79}$ on Brazilian studies at IAQ meetings around the world. Three acknowledge funding from CIAR. ${ }^{76} 7779$

In Chile, an IAQ study was discussed in a meeting held in 1992 between Rupp and Chilean consultants. ${ }^{80}$ According to Rupp's minutes, the study should not exceed $\$ 60000$ and efforts would be made to have CIAR cover $10 \%$ of the study "with Chiletabacos [BAT subsidiary in Chile] making a contribution to CIAR in that amount. The rest of the funding, because of tax considerations, would be contributed by Chiletabacos to the University of Chile" ${ }^{\prime 40}$

In 1995, Gil (Chilean consultant) published a paper in the Revista Médica Chilena entitled "Influencia de la contaminación atmosférica en la calidad de aire de interiores [Influence of outdoor pollution on indoor air quality]." ${ }^{\prime 1}$ The paper states that research funding was received from the European Community, the British Council, the American States Organization, and from the Chilean Organization FONDECYT; it does not mention the tobacco industry. The paper's conclusion matches the industry's position on IAQ: that SHS is only a minor contributor to indoor pollution.

We found two more articles on indoor air pollution in which Gil appears as author. Neither acknowledges funding from the tobacco industry. ${ }^{82}{ }^{83}$

Articles to discredit the science linking SHS with disease Consultants published articles in regional and international journals according to instructions given by $\mathrm{C} \& \mathrm{~B}$. The industry seemed particularly concerned about the growing case that SHS causes heart disease. ${ }^{84} 85$ In 1992 Rupp reported to industry representatives in Argentina that Burger and Alvarez were to write a review article on SHS and cardiovascular diseases to "be distributed in Argentina on a selective, carefully targeted basis by Alvarez as well as by industry representatives. Some journalists might be encouraged to write their own articles using the Burger/Alvarez article as the stepping off point." ${ }^{41}$

The article "Relation of smoking on the environment and coronary disease" ${ }^{\prime \prime 66}$ was published in Gacéta Médica de Caracas. It critiques the studies published on the relation between SHS and heart disease and concludes that it cannot be proven, mirroring well established industry criticisms of all research on SHS (inadequate control for other risk factors, misdiagnosis, missclassification of smoker status and SHS exposure). The journal Gacéta Médica de Caracas is not indexed in PubMed or on the Institute for Scientific Information ISI journal citation report (http://jcrweb.com/ accessed 25 March 2002). Therefore we were unable to assess the quality of this journal. C\&B distributed the article among industry representatives in Latin America to fuel the controversy about SHS. ${ }^{87} 88$

Such work continued; the Latin Project's 1994 budget indicates that, among other consultants, Alvarez was expected to "Write one article on the science of ETS, to be published in Acta Cardiologica. A suggested topic would be animal studies that antismoking activists in the United States have suggested support a plausible association between ETS exposure and heart disease." ${ }^{\prime 4}$ We searched PubMed and LILACS (Literatura Latino Americana e do Caribe em Ciencias de Saude) and were unable to find papers authored by Alvarez. Therefore, we were not able to determine if this paper was actually published. It appears, however, that even if it was, publication did not appear in a major medical journal.

\section{Regional symposia}

The tobacco industry organised and funded at least two symposia in Latin America between 1993 to 1995, in Quito, Ecuador and Buenos Aires, Argentina.

In Quito from 26-27 October 1993, consultant Raad organised a symposium at CIESPAL. ${ }^{149}$ CIESPAL is an international non-governmental organisation founded in 1959 by the Ecuadorian government, the National University of Ecuador, and the United Nations Educational, Scientific, and Cultural Organization (UNESCO). Its main objective is to study social communication in all its forms. The Latin America ETS Project: strategy and budget proposal for 1994 reports that this symposium aims to "provide the consultants a forum of unsurpassed prestige in the region for introducing the indoor air quality issue to the Latin American media." ${ }^{14}$ A budget of $\$ 130000$ was set aside for the symposium. ${ }^{90}$ Scientists from the countries included in the Latin Project ${ }^{62}$ and 40-60 journalists attended. The symposium received wide media coverage in the radio and television, ${ }^{91}$ as the tobacco industry had hoped.

Alfaro wrote the summary of the symposium. ${ }^{62}{ }^{64}$ A letter from $\mathrm{C} \& \mathrm{~B}$ to $\mathrm{PM}^{28}$ reported that "The goal, as we discussed, is 
to publish the article in the next edition of Dr. Alfaro's journal, Ciencias Ambientales, and perhaps to distribute reproductions of the article to Latin American journalists through CIESPAL." ${ }^{\prime 3}$ The summary ends with a number of implications derived from the symposium that reflect well established tobacco industry positions on SHS:

The results of the various indoor air quality monitoring studies reported at the CIESPAL symposium suggest that, to a large extent, the strategies that have been proposed in North America and Europe for addressing indoor air quality problems-such as enhanced ventilation rates and smoking restrictions-may not be appropriate for Latin America.

It is also clear from the CIESPAL conference that the indoor air pollution sources that need to be addressed in Latin America are different from those that have been addressed in North America and Europe. Smoking or ETS, to take only one example, was not found to be presenting significant problems in any of the studies reported on at the CIESPAL conference. By contrast, heating and cooking practices were found to be major contributors to indoor air pollution, suggesting the need for careful attention to the location and venting of such units. In addition, efforts to improve building hygiene (e.g., cleaning and disinfecting air handling ducts in buildings served by mechanical ventilating systems) are clearly called for, as are efforts to educate building owners and managers concerning other steps that can be taken to improve building system performance. ${ }^{62}$ [emphasis added]

$\mathrm{C} \& \mathrm{~B}$ edited the proceedings of the symposium before it was published in Ciencias Ambientales [Environmental Sciences], the journal of the School of Environmental Sciences at the National University of Costa Rica, which Alfaro edited. ${ }^{57}$ Rupp reported to other industry lawyers and executives, "Once all of the draft [of the CIESPAL Monograph] have arrived here [to $\mathrm{C} \& \mathrm{~B}]$, our plan is to turn them around promptly and also to draft an overall summary in a form that can be published in the Alfaro journal."'92

The second industry organised meeting was in Buenos Aires in July 1995. As early as 1992, in a meeting held in Buenos Aires between Argentine consultants, industry representatives, and Rupp, Alvarez and Dr Osvaldo Fustinoni (president of the Academy of Sciences of Buenos Aires) are mentioned as organisers of the conference.

Dr Alvarez indicated during our meeting that he believes that he and Dr. Fustinoni would be able to convince the Argentine National Academy of Sciences and National Academy of Medicine to sponsor and host a major regional meeting on ETS/indoor air issues . . . He [Dr. Alvarez] recommends that the meeting be open and that arrangements be made to accommodate up to 300 participants. ${ }^{41}$

The conference was proposed in the 1994 budget for the Latin

Project:

In order to provide basis for regional media initiatives, we $[C \& B]$ strongly recommend that a major indoor air quality conference be held in Buenos Aires around the middle of the year ... Efforts would be made to have the
Academy of Sciences of Buenos Aires sponsor the event and to encourage a prominent government official to open the conference. Scientists participating in the industry's Europe and Asia programs could be invited to the conference as well. ([the budget is] $\$ 150,000)^{18}$

Fustinoni, who in 1991 was president of the National Academy of Sciences of Buenos Aires, did not want any direct relationships with the industry, but C\&B viewed him as "clearly a moderate on ETS issue, and is so well known and respected in Argentina, we should endeavor to send work his way."32 Despite his reservations, Fustinoni worked with the industry as an organiser of the Buenos Aires symposium and as the author of a review of the science of ETS..$^{21}{ }^{41}$

The conference "Second International Symposium on New Advances in Ambient Air and Cardio-respiratory Illnesses"93 was hosted by National Academy of Sciences of Buenos Aires and sponsored by tobacco industry funded Indoor Air International. ${ }^{14}$ Indoor Air International, also known as International Association on Indoor Air Quality, was founded in 1989. ${ }^{94}$

Fustinoni and Alvarez made presentations at the conference. Fustinoni was the honorary president and Alvarez the president of the scientific committee. ${ }^{93}$ Among the speakers supporting the industry's position ${ }^{95}$ were industry American consultant Philip Witorsch and former New Mexico governor Garrey Carruthers, who was one of the nominal leaders of the industry's "sound science coalitions" established to attack the scientific evidence linking SHS and disease. ${ }^{6}$

Publication of the proceedings in Spanish was planned in the 1994 industry's strategy and budget proposal of the Latin American ETS Project. Titled Indoor air quality in Latin America, it "would provide the basis for a series of media initiatives both in Argentina and throughout the region, on indoor air quality and ETS issues." ${ }^{14}$ We could not locate a publication under this name, so do not know if the proceedings were published as planned.

\section{Lobbying}

PMI and BAT used their Latin Project consultants to lobby government officials. Consultants would "in some cases, make formal or informal scientific presentations to government officials considering adopting smoking restriction legislation."18 PM monitored legislation in all Latin American countries, ${ }^{96}$ including restrictions on warning labels, tar and nicotine constituent level, advertising, sampling, sports sponsorship, public smoking and vending machines. PM's first strategic objective in 1993 was: "Assist the affiliates [PMI affiliates in Latin America] in Preventing Passage of Legislation that Would Ban or Restrict Smoking in Public/Private Places." ${ }^{97}$

Argentina is the most notable case of how industry consultants lobbied government officials. A 1991 C\&B memorandum notes that Alvarez was chosen as a consultant, among other reasons, because he was "a technical and scientific advisor to Carlos Menem, the President of Argentina" ${ }^{\prime 32}$ [emphasis added]. Alvarez organised dinners with government officials and important press members, as well as met with current or former US Congress members and consultant scientists to address the "inappropriateness of smoking restrictions in view of other problems and challenges confronting Argentine policymakers." ${ }^{41}$ He billed C\&B \$20 000 for his "work done to establish the scientific arguments of the relation between ETS and disease which in due course were handed in to the Argentine Executive authorities." ${ }^{9899}$

On 30 September 1992 the Argentine Senate approved the "Neri Bill" which sought to end all tobacco advertising, promotion, and sampling, and severely limit smoking in public places. A strong lobbying campaign that relied on Alvarez's 
personal connections with President Carlos Menem convinced Menem to veto the law on 13 October $1992 .{ }^{100}$ According to Rupp:

The reports we [C\&B] have received indicate that Dr. Carlos Alvarez played a very useful role in the larger industry efforts to defeat, and then convince President Menem to veto the antitobacco legislation approved by the Argentine Parliament at the end of 1992. Dr. Alvarez activities included conversations with Senators from both parties and a series of conversations with President Menem as well as President Menem's brother, who serves as President of the Argentine Senate. Dr. Alvarez also provided President Menem with a briefing package and covering letter that pointed out that the smoking restrictions that had been proposed lacked solid scientific basis. According to Dr. Alvarez, Dr. Fustinoniwhile aware of the pending legislation-did not provide any substantial assistance. ${ }^{41}$ [emphasis added]

The relevance of this veto was highlighted in a letter written by Cesar Rodriguez (general manager, corporate affairs, PMI Latin America) and distributed to all PMI branches around the world:

Many lessons were learned in the process of opposing the Senate's action and obtaining a President veto including:

1) The importance of having clearly articulated messages to convey to the public and political leaders.

2) The need to create an environment in which Presidential veto would be politically feasible.

\section{3) A Presidential veto of a bill banning tobacco advertis- ing can have a domino effect in neighboring countries. ${ }^{101}$}

Venezuela represents another example of successful lobbying by the tobacco industry. In the 1990 "Venezuela Corporate Review" of CATANA (C.A. Tabacalera Nacional, a PM subsidi$\operatorname{ary}^{12}$ ) anti-smoking legislation is mentioned as a main issue affecting the industry. According to the review, Municipal Decree $\mathrm{N}[\mathrm{r}] \mathrm{H}$ of Caracas, Venezuela, would ban outdoor advertising, mandate a smoking and non-smoking section in restaurants, and prohibit sales of cigarettes in kiosks and sales to people under 18 years of age. Legal actions and intense lobbying to stop the decree were started by CATANA, which generated wide media coverage against enactment of the decree, negotiations with the mayor, verbal commitments from politicians to help reverse the decree, and finally the fact that the decree was not enforced. ${ }^{102}$ Furthermore, in 1992 Venezuelan consultants and industry representatives ${ }^{103}$ met to discuss the anti-smoking legislation that might be considered by the Congress in 1993. According to Rupp's memo of the meeting, [industry representatives] were "reasonably confident of the industry's ability to defeat the legislation without further assistance." ${ }^{\prime 2}$ In addition, the visit of former US Congress members would be used to "raise appropriate questions about the ETS documents that are being prepared at the Environmental Protection Agency in the United States and (b) discuss the negative consequences of smoking restrictions." ${ }^{42}$

Consultants were also used to monitor the Pan American Health Organization (PAHO). In a meeting held in Caracas, Venezuela, between local industry officials, consultant Dr Eduardo Souchon, and Rupp, it is noted that the industry

\section{What this paper adds}

Latin America represents an important market for the tobacco industry. Smoke-free workplaces and public places significantly reduce cigarette consumption and tobacco industry revenues. As elsewhere in the world, the tobacco industry has fought against such restrictions. Laws on smoking restrictions are still weak and rarely enforced in Latin America.

This analysis of previously secret tobacco industry documents reveals how the industry has hired consultants, lobbied government officials and the media, and conducted research in Latin America in order to successfully divert the attention from secondhand smoke and avoid meaningful smoking restrictions. By being aware of this activity, Latin American governments, public health practitioners, and health care providers, should be able to counter these activities and implement effective smoke-free environment legislation and regulations.

monitored WHO/PAHO activities in this country. Rupp reported that the local industry officials:

asked us $[C \& B]$ to explore prior to the industry meeting in Miami what additional efforts might be made to obtain advance warning of initiatives planned by $\mathrm{WHO} / \mathrm{PAHO}$ for the Latin Region. We agreed to discuss this issue with Dr. Alvarez, who may have contacts with PAHO representatives in Buenos Aires, and also to begin making discreet inquiries of PAHO Washington staff members with whom we have had contacts in the past. $^{42}$

\section{DISCUSSION}

Just as in the rest of the world, ${ }^{5} 811104105$ the tobacco industry hired consultants, financed research, organised "scientific" meetings and media briefings, and influenced policy development throughout Latin America since the early 1990s. C\&B, acting on PMI's and BAT's behalf, worked to minimise obvious connections between consultants and the industry to prevent the consultants from being viewed as partisans for the industry and so compromise the perception that they were neutral experts on SHS. As elsewhere, ${ }^{78}$ the industry's role was not publicly disclosed, even though industry lawyers and scientists played an active role in training and organising the consultants and, in some cases, editing papers and studies published under the consultants' authorship.

These strategies mirrored similar strategies in the USA and Europe. In 1993 Philip Morris started its "sound science" programme whose objective was to stimulate criticism of the 1992 US Environmental Protection Agency report ${ }^{19}$ that identified SHS as a class A human lung carcinogen and the cause of other serious respiratory problems. In Europe it launched a similar programme. The "good epidemiology program" sought to counter a European study ${ }^{106}$ evaluating the risk of lung cancer among those exposed to SHS. ${ }^{6}$ In Latin America, the tobacco industry infiltrated the PAHO. ${ }^{107}$

As in the USA, ${ }^{108}$ industry sponsored research in Latin America focused on generating local data to support the industry's position that SHS is not a serious problem for Latin America. By focusing on other sources of IAQ contamination the tobacco industry sought to divert the attention away from SHS by presenting it as a "minor" contributor to IAQ contamination. These results were then publicised, ${ }^{45}$ such as through the industry sponsored CIESPAL and Buenos Aires symposia. ${ }^{62}$

The industry was successful in co-opting not only physicians but chemists and environmentalists affiliated with 
national universities. It is particularly noteworthy that the industry was able to collaborate with the Argentine Academy of Sciences by working closely with its president Fustinoni. By doing so, the industry gained support from a prestigious academic institution in Latin America and earned an extra venue to publicise its results. From this standpoint, we can say that the industry was more successful in Latin America than what it was in North America. In the latter the quality and prestige of their consultants was not as good as it was in the former. In addition, in contrast to North America, their success is highlighted by the fact that after 10 years Latin American consultants' ties to the tobacco industry have not been exposed to the public.

The tobacco industry also influenced policy makers in Latin America through its consultants. The most notable example is Argentina, where they successfully managed to have President Menem veto the anti-tobacco bill (the "Neri Bill").

The involvement of tobacco industry lawyers in the selection of projects to be funded by the industry is not peculiar to Latin America. In the USA, industry lawyers used its Council for Tobacco Research to finance projects and consultancies designed to support the industry's position on both smoking and SHS through the secret Special Accounts 4 and $5 .^{7109}$ Later, the industry created CIAR to provide a similar mechanism for studies on SHS, SHS exposure, IAQ, and the effectiveness of ventilation in controlling SHS. ${ }^{61}$ In Latin America, as with the rest of CIAR funded special projects, results were used to generate good publicity for the industry, to deflect attention away from tobacco as a health hazard, and to attempt, sometimes surreptitiously, to influence policymakers.

Tobacco control measures in Latin America remain weak and rarely enforced. ${ }^{12}$ It was not until 2001 that PAHO made SHS a priority for Latin American countries, ${ }^{110} 10$ years after the industry started working on the issue. The fact that tobacco control measures have been delayed and undermined is the result of many factors, including lack of understanding of the epidemiologic transition, lack of awareness on the need for chronic disease preventive measures, lack of political will, and misinformation of health care professionals. The success of the industry in developing and putting into practice a project that would contribute to feeding each one of these factors cannot be underestimated and should be highlighted.

In Latin America the tobacco industry has successfully applied the methods it developed elsewhere in the world to reach its goal of preventing the issue of SHS from taking root. This goal was accomplished through the development of a network of well placed physicians and scientists. These consultants were trained and organised by the industry's lawyers, and used with the media and policy makers while the industry worked actively to minimise public awareness of their connections to the industry. Health care professionals and tobacco control professionals in Latin America need to understand and expose these relationships in order to halt the tobacco epidemic in Latin America.

\section{ACKNOWLEDGEMENT}

This work was supported by the American Legacy Foundation and National Cancer Institute Grant CA-87472.

\section{Authors' affiliations}

J Barnoya, S Glantz, Center for Tobacco Control Research and Education, Cardiovascular Research Institute and Institute for Health Policy Studies, University of California, San Francisco, California, USA

\section{REFERENCES}

1 Glantz S. Back to basics: Getting smoke free workplaces back on track [editorial]. Tobacco Control 1997;6:164-6.

2 Chapman S, Borland R, Hill D, et al. Why the tobacco industry fears the passive smoking issue. Int J Health Serv 1990;20:417-27.
3 Fichtenberg CM, Glantz SA. Effect of smoke-free workplaces on smoking behaviour: systematic review. BM 2002;325:188.

4 Fichtenberg CM, Glantz SA. Association of the California tobacco control program with declines in cigarette consumption and mortality from heart disease. N Engl J Med 2000;343:1772-7.

5 Drope J, Chapman S. Tobacco Industry efforts at discrediting scientific knowledge of environmental tobacco smoke: a review of internal industry documents. J Epidemiol Community Health 2001;55:588-94.

6 Ong EK, Glantz SA. Constructing "sound science" and "good epidemiology": tobacco, lawyers, and public relations firms. Am J Public Health 2001;91:1749-57.

7 Bero L, Barnes DE, Hanauer P, et al. Lawyer control of the tobacco industry's external research program. The Brown and Williamson documents [published erratum appears in JAMA 1997;277:885]. JAMA 1995;274:241-7.

8 Ong EK, Glantz SA. Tobacco industry efforts subverting International Agency for Research on Cancer's second-hand smoke study. Lancet 2000;355: 1253-9.

9 Glantz S, Slade J, Bero L, et al. Lawyer management of scientific research. In: The cigarette papers, 1 st ed: San Francisco: University of California, 1996:539.

10 Barnes DE, Hanaver P, Slade J, et al. Environmental tobacco smoke. The Brown and Williamson documents. JAMA 1995;274:248-53.

11 Muggli ME, Forster JL, Hurt RD, et al. The smoke you don't see: uncovering tobacco industry scientific strategies aimed against environmental tobacco smoke policies. Am J Public Health 2001;91:1419-23.

12 Corrao MA GG, Sharme N, Shookoohi DF, eds. Tobacco control country profiles, American Cancer Society. Atlanta, Georgia: American Cancer Society, 2000

13 Anon. Regional public affairs plan and budget for 93 Central and South America ETS Consultant Project. 23 September 1993. Access date: 27 July 2001. Bates No. 2503017261/7268. URL: http:// www.pmdocs.com/getallimg.asp?if=avpidx\&DOCID=2503017261/ 7268

14 Anon. Latin America ETS Project: strategy and budget proposal for 94 . 1994. www.pmdocs.com. Access date: 29 August 2001. Bates No. 2503017246/17260. URL: http://www.pmdocs.com/ getallimg.asp? if=avpid $\&$ DOCID $=2503017246 / 7260$

15 Rupp JP. No title. Covington \& Burling. 25 November 1992 www.pmdocs.com. Access date: 25 January 2002. Bates No. 2023591402. URL: http://www.pmdocs.com/ getallimg. asp? if =avpid $x \& D O C I D=2023591402$

16 Anon. Preliminary 1994 consultants program proposal. 1994 www.pmdocs.com. Access date: 8 March 2002. Bates No. 2023590685/0687. URL: http://www.pmdocs.com/ getallimg. asp? if =avpid $\&$ \&DOCID $=2023590685 / 0687$

17 Whist A. ETS. Philip Morris. 11 July 1989. Access date: 27 July 2001 Bates No. 2500048772/8781. URL: http://www.pmdocs.com/ getallimg.asp?if=avpidx\&DOCID $=2500048772 / 8781$

18 Rupp JP, Davies PS. Proposed 94 budget for the Latin American ETS consultant program. Covington \& Burling. 15 September 1993. Access date: 10 August 2001. Bates No. 2503017276/7279. URL: http://www.pmdocs.com/ getallimg. asp? if=avpidx\&DOCID $=2503017276 / 7279$

19 US Environmental Protection Agency. Respiratory health effects of passive smoking: lung cancer and other disorders. Washington, DC: Office of Health and Environmental Assessment, 1992. (Publication No EPA/600/6-90/006F.)

20 Anon. No title. 8 January 1993. Access date: 10 August 2001. Bates No. 2503007280/7285. URL: http://www.pmdocs.com/ getallimg. asp?if=avpid $x \& D O C I D=2503007280 / 7285$

21 Rupp JP. No title. Covington \& Burling. 18 September 1992. Access date: 29 August 2001. Bates No. 2023591414/2023591417. URL: http://www.pmdocs.com/ getallimg.asp?if=avpidx\&DOCID=2023591414/1417

22 Anon. Dr Bruce D Davies. Manager of Scientific Affairs for Latin America and the Brazilian Region responsibilities and objectives for 1997. 1997. www.pmdoc.com. Access date: 21 March 2002. Bates No. 2074413805/3806. URL: http://www.pmdocs.com/ getallimg asp?if=avpidx\&DOCID $=2074413805 / 3806$

23 Anon. Dr Bruce D Davies. Manager of Scientific Affairs for Latin American and the Brazilian Region. Resposibilities and Objectives for 1997. Mid-year Update on Progress. 1997. Legacy Tobacco Document Library. Access date: 21 March 2002. Bates No. 2063638296/8299. URL: http://dlxs.ckm.ucsf.edu/cgi/ getdoc?tid=pki67e00\&fmt=pdf\&ref=results

24 Anon. Technical Activity Summary. Latin America Consultant Program. 1998. www. pmdocs.com. Access date: 7 February 2002. Bates No. 2060565700/5701. URL: http://www.pmdocs.com/ getallimg. asp? $i f=$ avpid $\& D O C I D=2060565700 / 5701$

25 Davies BD. SIM Projects and activities, 1998. 1998. Legacy Tobacco Document Library. Access date: 21 March 2002. Bates No. 2060566211. URL: http://dlxs.ckm.ucsf.edu/cgi/ getdoc?tid=ikd $13 \mathrm{e} 00 \& \mathrm{fmt}=$ pdf\&ref=results

26 Boyse S. Latin American ETS Consultancy Programmes. BAT. 25 July 1991. BATCo Guilford Depository. Bates No. 300515203/5229.

27 Gonzalez AM. Letter to Sharon Boyse. Responsibilities for consultants Philip Morris. 21 March 1991. BATCo Guilford Depository. Bates No. $300515301 / 5302$

28 Anon. Corporate affairs workshop the Carlton Hotel, Washington D.C. 950418-950421. 21 April 1995. www.pmdocs.com. Access date: 14 
January 2002. Bates No. 2045677642/7656. URL: http:// www.pmdocs.com/getallimg. asp?if=avpidx\&DOCID=2045677642/ 7656

29 Rodriguez C. Scientific Consultancy Program. Philip Morris. 22 March 1991. www.pmdocs.com. Access date: 25 January 2002. Bates No. 2500017548/7549A. URL: http://www.pmdocs.com/ getallimg.asp? if=avpid $x \& D O C I D=2500017548 / 7549 \mathrm{~A}$

30 Davies PS. No title. Covington \& Burling. 4 January 1993 http://dlxs.ckm.ucsf.edu/. Access date: 21 February 2002. Bates No. 2023591326. URL: http://dlxs.ckm.ucsf.edu/cgi/ getdoc?tid =wwf46e00\&fmt=tif\&ref=results

31 Rupp JP. No title. 12 October 1993. Access date: 22 October 2001 Bates No. 2025838397/8398. URL: http://www.pmdocs.com/ getallimg. asp?if=avpidx\&DOCID $=2025838397 / 8398$

32 Anon. No title. Philip Morris. 1991. www.pmdocs.com. Access date: 7 February 2002. Bates No. 2503001508/1519. URL: http://www.pmdocs.com/

getallimg.asp?if=avpid $\&$ DOCID $=2503001508 / 1519$

33 Anon. Memorandum - RE: Latin America ETS Project. Covington \& Burling. 26 March 1992. Access date: 27 July 2001. Bates No. 2503007503/7507. URL: http://www.pmdocs.com/ getallimg asp? $i f=$ avpidx\&DOCID $=2503007503 / 7507$

34 Proctor CJ. Letter to Sharon Boyse regarding consultants training Covington \& Burling. 18 February 1992. BATCo Guilford Depository Bates No. 300515149/5152.

35 Ecobichon DJ, Warner JM. Environmental tobacco smoke: proceedings of the international symposium at McGill University, 1989. In: International Symposium on Environmental Tobacco Smoke, 1989. Montreal Canada: Lexington Books, 1989:389.

36 Davies PS. [Letter to Ana Molina]. C\&B. 23 March 1992. www.pmdocs.com. Access date: 18 March 2002. Bates No. 2500011459/1459A. URL: http://www.pmdocs.com/ getallimg.asp? if=avpidx\&DOCID=25000 $11459 / 1459 \mathrm{~A}$

37 Davies PS. Letter to Sharon Boyse. Covington \& Burling. 10 June 1992 BATCo Guilford Depository. Bates No. 300515062.

38 Rupp J. Meeting in San Jose relating to the ETS consultants program. 23 November 1992. Access date: 27 July 2001. Bates No. 2023591336/1348. URL: http://www.pmdocs.com/ getallimg. asp?if=avpidx\&DOCID $=2023591336 / 1348$

39 Rupp JP. Meetings in Quito relating to the ETS Consultants Program. Covington \& Burling. 23 November 1992. Access date: 27 July 2001. Bates No. 2023591380/1386. URL: http://www.pmdocs.com/ getallimg. asp?if=avpidx\&DOCID $=2023591380 / 1386$

40 Rupp JP. Meetings in Santiago relating to the ETS consultants program. Covington \& Burling. 15 November 1992. Access date: 27 July 2001. Bates No. 2023591362/1368. URL: http://www.pmdocs.com/ getallimg. asp? $i f=a v p i d x \& D O C I D=2023591362 / 1368$

41 Rupp JP. Meetings in Buenos Aires relating to the ETS Consultants Program. Covington \& Burling. 13 November 1992. Access date: 29 August 2001. Bates No. 2023591390/1399. URL: http:// www.pmdocs.com/getallimg.asp? if=avpidx\&DOCID $=2023591390 /$ 1399

42 Rupp JP. Meeting in Caracas relating to the ETS consultants program. Covington \& Burling. 23 November 1992. www.pmdocs.com. Acces date: 27 July 2001. Bates No. 2023591371/1376. URL: http://www.pmdocs.com/ getallimg.asp? $i f=$ avpid $x \& D O C I D=2023591371 / 1376$

43 Armitage AK, ed. Other people's tobacco smoke. East Yorkshire: Galen Press, 1991.

44 Gonzalez AM. No title. 25 July 1991. Legacy Tobacco Document Library. Access date: 26 March 2002. Bates No. 2503001506/1507. URL: http://dlxs.ckm.ucsf.edu/cgi/ getdoc?tid=rme87e00\&fmt=gif\&ref=results\&bates=2503001506/150 7

45 Bero LA, Galbraith A, Rennie D. Sponsored symposia on environmental tobacco smoke. JAMA 1994;271:612-7.

46 Rupp JP. No title. Covington \& Burling. 4 December 1992 www.pmdocs.com. Access date: 24 January 2002. Bates No. 2503011713/1716. URL: http://www.pmdocs.com/ getallimg.asp?if=avpidx\&DOCID=2503011713/1716

47 Anon. Partió a Grecia Carlos B. Alvarez. Gonzalez Taboada y Asociados, S.A. De Comunicacion. 10 April 1992. Guilford Depository. Bates No. 300515039

48 Anon. Argentina en un acto cientifico. Gonzalez Taboada y Asociados S.A. De Comunicacion. 20 April 1992. BATCo Guilford Depository. Bates No. 300515040

49 Anon. Conferencia. Gonzalez Taboada y Asociados, S.A. De Comunicacion. 19 April 1992. BATCo Guilford Depository. Bates No. 300515041

50 Anon. Contaminacion en los espacios cerrados. Gonzalez Taboada y Asociados, S.A. De Comunicacion. 21 May 1992. BATCo Guilford Depository. Bates No. 300515043.

51 Anon. Casas enfermas. Gonzalez Taboada y Asociados, S.A. De Comunicacion. 7 June 1992. BATCo Guildord Depository. Bates No. 300515044

52 Anon. Edificios Malditos. Gonzalez Taboada y Asociados, S.A. De Comunicacion. 22 May 1992. BATCo Guilford Depository. Bates No. 300515045

53 Anon. Medio ambiente interior y las enfermedades cardiovasculares. Gonzalez Taboada y Asociados S.A. de Comunicacion. 17 May 1992. BATCo Guilford Depository. Bates No. 300515047

54 Davies PS. Letter to Dr. Carlos Alvarez. Covington \& Burling. 8 May 1992. BATCo Guilford Depository. Bates No. $300515101 / 5107$.
55 Kennedy GE, Bero LA. Print media coverage of research on passive smoking. Tobacco Control 1999;8:254-60.

56 Anon. Memorandum outdoor air pollution and indoor air quality: resources and options. Covington \& Burling. 14 May 1994. Access date: 10 August 2001. Bates No. 2503018977/8980. URL: http://www.pmdocs.com/

getallimg.asp?if=avpidx\&DOCID=2503018977/8980

57 Alfaro MdR, Camargo CL. Measurements of indoor air quality in six Central American countries. 1992. www.pmdocs.com. Access date: 4 December 2001. Bates No. 2503011692/1702. URL: http://www.pmdocs.com/ getallimg.asp?if=avpidx\&DOCID=250301 1692/1702

58 Boyse S. Central American Indoor Air Quality Research Project. BAT. 22 April 1992. BATCo Guilford Depository. Bates No. 300515125/5126.

59 Alfaro MdR, Gonzalez C. Proposal. Indoor Air Quality Field Study. Central America. BAT. 1992. BATCo Guilford Depository. Bates No. $300515110 / 5116$

60 Alfaro MdR. Application for research contract measurement of indoor air quality in six Central American countries. Universidad Nacional de Costa Rica. 1992. www.pmdocs.com. Access date: 8 February 2002. Bates No. 2023591457/1459. URL: http://www.pmdocs.com/ getallimg.asp?if=avpidx\&DOCID $=2023591457 / 1459$

61 Barnes DE, Bero LA. Industry-funded research and conflict of interest: an analysis of research sponsored by the tobacco industry through the Center for Indoor Air Research. Journal of Health Politics, Policy and Law 1996;21:515-42.

62 Alfaro MdR. Summary of the proceedings of the CIESPAL symposium on indoor air quality in Latin America. Philip Morris. December 1993. Access date: 19 October 2001. Bates No. 2025841850/1862. URL: http://www.pmdocs.com/ getallimg.asp?if=avpid $x \& D O C I D=2025841850 / 1862$

63 Davies PS. No Title. Covington \& Burling. 5 January 1994. Access date: 21 August 2001. Bates No. 2503017280/7282. URL: http://www.pmdocs.com/ getallimg.asp?if=avpid $\&$ \&OCID $=2503017280 / 7282$

64 Davies PS. No title. Covington \& Burling. 28 January 1994. Access date: 13 September 2001. Bates No. 2503017270/7271. URL: http://www.pmdocs.com/ getallimg. asp?if=avpidx\&DOCID $=2503017270 / 7271$

65 Rupp JP. No title. Covington \& Burling. 23 November 1992. Legacy Tobacco Documents Library. Access date: 21 February 2002. Bates No. 2023591335. URL: http://www.pmdocs.com/ getallimg. asp? if=avpidx\&DOCID $=2023591335$

66 Alfaro MdR. Characterisation of indoor air quality in large urban centres in Central America. Indoor \& Built Environment 1997;6:337-43.

67 Carchman R, Davies B. Voucher. Philip Morris, USA. 4 August 1997. www.pmdocs.com. Access date: 13 March 2002. Bates No. 2074416123/6124. URL: http://www.pmdocs.com/ getallimg. asp?if=avpidx\&DOCID=2074416123/6124

68 Alfaro MdR, Davies B. R5827. 7 September 1997. www.pmdocs.com. Access date: 13 March 2002. Bates No. 2074416125. URL: http://www.pmdocs.com/

getallimg .asp? if=avpidx\&DOCID=2074416125

69 Alfaro MdR. RE: Address. 16 September 1997. www.pmdocs.com. Access date: 13 March 2002. Bates No. 2074416113. URL: http://www.pmdocs.com/ getallimg.asp?if=avpidx\&DOCID $=2074416113$

70 Miguel AH. No title. 25 September 1992. Legacy Tobacco Documen Library. Access date: 21 March 2002. Bates No. 87803525/3537. URL: http://dlxs.ckm.ucsf.edu/cgi/ getdoc?tid=cil2 l e00\&fmt=pdf\&ref=results

71 Miguel AH, de Aquino Neto FR, Cardoso JN, et al. Characterization of indoor air quality in the cities of Sao Paulo and Rio de Janeiro, Brazil. Environmental Science and Technology 1995;29:338-45.

72 Collins J, Massambani O, Miguel AH, et al. Proposal acquisition of source signatures and receptor modeling of fine particles and VOC impacting indoor air quality in Santiago de Chile and Sao Paulo, Brazil. 1998. Legacy Tobacco Document Library. Access date: 21 March 2002 Bates No. 2063608126/8164. URL: http://dlxs.ckm.ucsf.edu/cgi/ getdoc?tid=mqm67e00\&fmt=pdf\&ref=results

73 Reif H. Applied Studies. 1998 Funding cycle. 11 November 1998. www.pmdocs.com. Access date: 8 February 2002. Bates No. 2063596723/6728. URL: http://www.pmdocs.com/ getallimg.asp? if=avpidx\&DOCID=2063596723/6728

74 Reif H. Center for Indoor Air Research 1998 Funding Cycle. Philip Morris, Europe. 1998. Access date: 8 February 2002. Bates No. 2063596693/6698. URL: http://www.pmdocs.com/ getallimg.asp? $i f=$ avpidx\&DOCID $=2063596694 / 6698$

75 Ellis C. No title. 10 September 1998. Legacy Tobacco Documen Library. Access date: 21 March 2002. Bates No. 2060570491. URL: http://dlxs.ckm.ucsf.edu/cgi/getdoc?tid=fib 13e00\&fmt=pdf\&ref=results

76 Aquino Neto F, Cardoso JN, Pereira AS. Analysis of nicotine from indoor air by HRGC with capillary columns. 25 June 1993. Legacy Tobacco Document Library. Access date: 21 March 2002. Bates No. 2503000458/0459. URL: http://dlxs.ckm.ucsf.edu/cgi/ getdoc?tid=hva42e00\&fmt=pdf\&ref=results

77 Afonso J, Aquino Neto F, Cardoso JN, et al. Sampling and characterization of aerosols and gaseous components in indoor atmospheres in urban cities of Brazil. May 21, 1993. Legacy Tobacco Document Library. Access date: 21 March 2002. Bates No. 2503000454/0457. URL: http://dlxs.ckm.ucsf.edu/cgi/ getdoc?tid=lbq $19 \mathrm{e} 00 \& \mathrm{fmt}=$ pdf\&ref=results 
78 Allen AG, Aquino Neto F, Cardoso JN, et al. Concentration and fate of airborne species in offices and restaurants located in cities affected by alcohol-fueled vehicles. 14 March 1993. Legacy Tobacco Document Library. Access date: 21 March 2002. Bates No. 2503000452/0453. URL: http://dlxs.ckm.ucsf.edu/cgi/ getdoc?tid=kbq $19 \mathrm{e} 00 \& \mathrm{fm}=$ pdf\&ref=results

79 Allen AG, Aquino Neto F, Cardoso JN, et al. An overview of the southeastern Brazil indoor air quality study (SEBIAQS): measurements of organic and inorganic aerosol and gas-phase species. March, 1993. Legacy Tobacco Document Library. Access date: 21 March 2002. Bates No. 2503000446/0451. URL: http://dlxs.ckm.ucsf.edu/cgi/ getdoc?tid=obq $19 \mathrm{e} 00 \& \mathrm{fmt}=$ pdf\&ref=results

80 Rupp JP. No title. Covington \& Burling. 23 November 1992. Legacy Tobacco Document Library. Access date: 21 February 2002. Bates No. 2023591361. URL: http://www.pmdocs.com/ getallimg.asp? $i f=a v p i d x \& D O C I D=202359136$

81 Gil L, Adonis M, Caceres L D, et al. Influencia de la contaminacion atmosferica en la calidad de aire interiores. Revista Medica Chilena 1995; 123:411-25.

82 Gil L, Caceres L D, Quiñones L, et al. Contaminación del aire en espacios exteriores e interiores en la ciudad de Temuco. Ambiente y Desarrollo 1997;XIII:70-8.

83 Adonis M, Gil L. Polycyclic aromatic hydrocarbon levels and mutagenicity of inhalable particulate matter in Santiago, Chile. Inhalation Toxicology 2000;12:1173-83.

84 Glantz SA, Parmley WW. Passive smoking and heart disease. Epidemiology, physiology, and biochemistry. Circulation 1991;83:1-12.

85 Taylor A, Johnson D, Kazemi H. Environmental tobacco smoke and cardiovascular disease. A position paper from the Council on Cardiopulmonary and Critical Care, American Heart Association. Circulation 1992;86:699-702.

86 Alvarez C, Burger B. Relation of smoking on the environment with coronary disease. Gaceta Medica de Caracas 1993;101:330-4

87 Davies PS. No title. Covington \& Burling. 19 December 1993. Legacy Tobacco Document Library. Access date: 21 February 2002. Bates No. 2025841929/1930. URL: http://www.pmdocs.com/ getallimg.asp? if=avpidx\&DOCID $=2025841929 / 1930$

88 Davies PS. No title. Covington \& Burling. 19 December 1993. Legacy Tobacco Document Library. Access date: 21 February 2002. Bates No. 2025841931/1932. URL: http://www.pmdocs.com/ getallimg. asp?if=avpidx\&DOCID=2025841931/1932

89 Antich E. PARG Suramericano. Bigott. 8 April 1993. BATCo Guildord Depository. Bates No. 500820718/0721

90 Davies PS. No title. Covington \& Burling. 27 May 1993. Access date: 3 October 2001. Bates No. 2023591273/1274. URL: http://www.pmdocs.com/ getallimg.asp? if=avpidx\&DOCID=2023591273/1274

91 Davies PS. No title. Covington \& Burling. 3 November 1993. Access date: 29 August 2001. Bates No. 2025841982/1984. URL: http://www.pmdocs.com/ getallimg.asp?if=avpidx\&DOCID $=2025841982 / 1984$

92 Rupp JP. Regarding status of various Latin American projects. Covington \& Burling. 8 December 1993. www.pmdocs.com. Access date: 25 January 2002. Bates No. 2023591257/1258. URL: http:// www.pmdocs. com/getallimg $\cdot$ asp? $i f=$ avpidx\&DOCID $=2023591257$ 1258

93 Anon. II Simposio international 'Nuevos Avances en la investigacion de medio ambiente y las enfermedades cardiorespiratorias.' 18 July 1995. www.pmdocs.com. Access date: 20 November 2001. Bates No. 2048771296/1297. URL: http://www.pmdocs.com/ getallimg.asp?if=avpidx\&DOCID=2048771296/1297

94 Gaisch H. Monthly Reports Highlights. Fabriques de Tabac Reunies, S.A. 21 October 1989. www.pmdocs.com. Access date: 24 January 2002. Bates No. 2021598978/8991. URL: http://www.pmdocs.com/ getallimg $\cdot$ asp? $i f=a v p i d x \& D O C I D=2021598978 / 8991$
95 Anon. Outline of events and arrangements for the Buenos Aires Conference. 23 May 1995. www.pmidoc.com. Access date: 20 November 2001. Bates No. 2048771294/1295. URL: http://www.pmdocs.com/ getallimg.asp? if=avpidx\&DOCID=2048771294/1295

96 Anon. Latin America Corporate Affairs Situation Report. Philip Morris October 1992. www.pmdocs.com. Access date: 25 January 2002. Bates No. 2025602719/2750. URL: http://www.pmdocs.com/ getallimg. asp? if=avpidx\&DOCID $=2025602719 / 2750$

97 Anon. Aurora Marina Gonzalez, Corporate Affairs Manager Latin America. 1993 Objectives. 1993. www.pmdocs.com. Access date: 25 January 2002. Bates No. 2503024142/4145. URL: http:// www.pmdocs.com/getallimg.asp? if=avpidx\&DOCID $=2503024142 /$ 4145

98 Alvarez C. Letter to John Rupp. Re: Fee. 1992. BATCo Guildord Depository. Bates No. 300543203

99 Davies PS. Letter to Jorge Basso, Argentina. 3 December 1992. BATCo Guildord Depository. Bates No. 300543199.

100 Anon. Veto of anti-tobacco law case analysis: Argentina. www.pmdocs.com. Access date: 4 December 2001. Bates No. 2046436804/6872. URL: http://www.pmdocs.com/ getallimg. asp? $i f=a v p i d x \& D O C I D=2046436807 / 6872$

101 Rodriguez C. Presidential veto of advertising ban - Argentina. Philip Morris. 7 December 1992. www.pmdocs.com. Access date: 25 January 2002. Bates No. 2023333152/3154. URL: http://www.pmdocs.com/ getallimg. asp? $i f=a v p i d x \& D O C I D=2023333152 / 3154$

102 Anon. Venezuela Corporate Affairs Review. CA Tabacalera Nacional. 18-19 July 1990. www.pmdocs.com. Access date: 8 February 2002. Bates No. 2500014698/4733. URL: http://www.pmdocs.com/ getallimg. asp?if=avpid $x \& D O C I D=2500014698 / 4733$

103 Rupp JP. No title. Covington \& Burling. 23 November 1992. Legacy Tobacco Document Library. Access date: 21 February 2002. Bates No. 2023591370. URL: http://www.pmdocs.com/ getallimg. asp? if $=$ avpidx\&DOCID $=2023591370$

104 Warner KE. Tobacco industry scientific advisors: serving society or selling cigarettes? Am J Public Health 1991;81:839-42.

105 Rennie D. Smoke and letters. JAMA 1993;270:1742-43.

106 Boffetta P, Agudo A, Ahrens W, et al. Multicenter case-control study of exposure to environmental tobacco smoke and lung cancer in Europe. J Ntl Cancer Inst 1998;90: 1440-50.

107 Committee of Experts on Tobacco Industry Documents. Tobacco company strategies to undermine tobacco control activities at the World Health Organization. Geneva: World Health Organization, 2000

108 Hirschhorn N, Bialous SA. Second hand smoke and risk assessment: what was in it for the tobacco industry? Tobacco Control $2001 ; 10: 375-82$.

109 Glantz S, Slade J, Bero L, et al. The cigarette papers. San Francisco: University of California, 1996.

110 Pan American Health Organization. PAHO launches smoke free america initiatives. Pan American Health Organization, 2001

111 Rupp JP. No title. Covington \& Burling. 23 November 1992. Access date: 27 July 2001. Bates No. 2023591387/1389. URL: http://www.pmdocs.com/ getallimg.asp?if=avpidx\&DOCID=2023591387/1389

112 de Siqueira CJP. Latin American ETS Consultancy Programmes. Souza Cruz. 1991. BATCo Guilford Depository. Bates No. 300515200

113 Anon. Latin American Candidate recommendations. 24 July 1991. www.pmdocs.com. Access date: 6 February 2002. Bates No. 2503001505. URL: http://www.pmdocs.com/ getallimg. asp? if=avpidx\&DOCID=2503001505

114 Rupp JP. Letter to Sharon Boyse and Aurora Gonzalez. Central American Field Study. Covington \& Burling. 2 April 1992. BATCo Guilford Depository. Bates No. 300515127/5128. 